University of Nebraska - Lincoln

DigitalCommons@University of Nebraska - Lincoln

Publications, Agencies and Staff of the U.S.

Department of Commerce

U.S. Department of Commerce

2011

\title{
Water chemistry and its effects on the physiology and survival of Atlantic salmon Salmo salar smolts
}

T. Liebich

USFWS,Trent_Liebich@fws.gov

S. D. McCormick

USGS

D. Kircheis

NOAA Fisheries

K. Johnson

Husson University

R. Regal

University of Minnesota - Duluth

See next page for additional authors

Follow this and additional works at: https://digitalcommons.unl.edu/usdeptcommercepub

Part of the Environmental Sciences Commons

Liebich, T.; McCormick, S. D.; Kircheis, D.; Johnson, K.; Regal, R.; and Hrabik, T., "Water chemistry and its effects on the physiology and survival of Atlantic salmon Salmo salar smolts" (2011). Publications, Agencies and Staff of the U.S. Department of Commerce. 286.

https://digitalcommons.unl.edu/usdeptcommercepub/286

This Article is brought to you for free and open access by the U.S. Department of Commerce at DigitalCommons@University of Nebraska - Lincoln. It has been accepted for inclusion in Publications, Agencies and Staff of the U.S. Department of Commerce by an authorized administrator of DigitalCommons@University of Nebraska - Lincoln. 


\section{Authors}

T. Liebich, S. D. McCormick, D. Kircheis, K. Johnson, R. Regal, and T. Hrabik 


\title{
Water chemistry and its effects on the physiology and survival of Atlantic salmon Salmo salar smolts
}

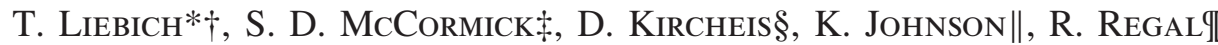 \\ AND T. HRABIK**
}

*USFWS, Izembek National Wildlife Refuge, 1 Izembek Street, Cold Bay, AK 99571, U.S.A., $\ddagger U S G S$, Silvio O. Conte Anadromous Fish Research Center, 1 Migratory Way, P. O. Box 796, Turners Falls, MA 01376, U.S.A., §NOAA Fisheries, Maine Field Station, 17 Godfrey Drive - Suite 1, Orono, ME 04473, U.S.A., ||Department of Chemistry, Husson University, 1 College Circle, Bangor, ME 04401, U.S.A., IDepartment of Mathematics and Statistics, University of Minnesota Duluth, Solon Campus Center 140, 1117 University Drive, Duluth, MN 55812, U.S.A., and **UMD Biology, James 1. Swenson Science Building 207, 1035 Kirby Drive, Duluth, MN 55812, U.S.A.

(Received 19 February 2010, Accepted 26 May 2011)

\begin{abstract}
The physiological effects of episodic $\mathrm{pH}$ fluctuations on Atlantic salmon Salmo salar smolts in eastern Maine, U.S.A., were investigated. During this study, S. salar smolts were exposed to ambient stream-water chemistry conditions at nine sites in four catchments for 3 and 6 day intervals during the spring $S$. salar smolt migration period. Plasma chloride, plasma glucose, gill aluminium and gill $\mathrm{Na}^{+}$- and $\mathrm{K}^{+}$-ATPase levels in $S$. salar smolts were assessed in relation to ambient stream-water chemistry during this migration period. Changes in both plasma chloride and plasma glucose levels of $S$. salar smolts were strongly correlated with stream $\mathrm{pH}$, and $S$. salar smolt mortality occurred in one study site with ambient stream $\mathrm{pH}$ between 5.6 and 5.8 during the study period. The findings from this study suggest that physiological effects on S. salar smolts are strongly correlated with stream $\mathrm{pH}$ and that in rivers and streams with low dissolved organic carbon (DOC) concentrations the threshold for physiological effects and mortality probably occurs at a higher $\mathrm{pH}$ and shorter exposure period than in rivers with higher DOC. Additionally, whenever an acidification event in which $\mathrm{pH}$ drops below 5.9 coincides with $S$. salar smolt migration in eastern Maine rivers, there is potential for a significant reduction in plasma ions of $S$. salar smolts.

Journal of Fish Biology (C) 2011 The Fisheries Society of the British Isles No claim to original US government works
\end{abstract}

Key words: aluminium; ATPase; chloride; DOC; glucose; pH.

\section{INTRODUCTION}

During the past century, Atlantic salmon Salmo salar L. 1758 populations have experienced decline on a global scale. In the U.S.A., S. salar have been extirpated from much of their historic range (Parrish et al., 1998) and the few remnant wild populations have declined in abundance to the extent that they have been federally listed as endangered and major restoration efforts are currently underway (Baum,

$\dagger$ Author to whom correspondence should be addressed. Tel.: +1 907532 2445; email: Trent_Liebich@ fws.gov 
1997; Fay et al., 2006). Over the past two centuries, S. salar populations in eastern Maine were reduced to a fraction of historic abundances, but remained relatively constant throughout the early to mid-1900s. In the 1990s, these populations experienced additional substantial declines, and have yet to recover. Acidification has since been identified as a possible contributory factor to $S$. salar declines in eastern Maine and in other areas of the north-eastern U.S.A. (Clegg et al., 2004). Acidic conditions are common in aquatic ecosystems throughout the north-eastern U.S.A. and frequently occur as episodic acidification events that reduce stream $\mathrm{pH}$ for days to weeks (Haines et al., 1990; Kahl et al., 1992; Johnson \& Kahl, 2005).

Decreases in stream $\mathrm{pH}$, as a result of acidification, can harm aquatic organisms (Haines, 1981; Schindler, 1988) and all life stages of $S$. salar are known to be negatively affected by acidification (Haines, 1981; Staurnes et al., 1993; Kroglund \& Staurnes, 1999). In addition to the effects of reduced $\mathrm{pH}$, the negative effects to aquatic biota owing to acidic deposition are often compounded by the enhanced mobilization of aluminium (Haines, 1981). Between $\mathrm{pH} 6.0$ and 8.0 aluminium is relatively insoluble and generally not toxic to aquatic species. Below $\mathrm{pH} 6 \cdot 0$, aluminium exists in a number of charged forms $\left(\right.$ e.g. $\left.\mathrm{Al}^{3+}\right)$ that increase in toxicity to aquatic organisms as $\mathrm{pH}$ decreases (Haines, 1981; Leivestad et al., 1987; Gensemer \& Playle, 1999). These charged forms of aluminium may exist in bound (organic) or unbound (inorganic) forms, with the latter generally thought to be the more toxic form in aquatic ecosystems.

The effects of low $\mathrm{pH}$ and inorganic aluminium on $S$. salar have been studied in detail in northern Europe where acidification results in chronic (year-round) low pH (Nyberg et al., 1995; Staurnes et al., 1995, 1996; Kroglund \& Staurnes, 1999; Kroglund et al., 2001; Ytrestoyl et al., 2001; Bjerknes et al., 2003) which has resulted in extirpation of $S$. salar in $>25$ Norwegian rivers (Hesthagen \& Hansen, 1991). Research has also found that $S$. salar smolts are more sensitive to acidic conditions than other life stages, and this sensitivity appears to increase as the parrsmolt transformation progresses (Staurnes et al., 1993, 1996; Monette \& McCormick, 2008).

A pH below 6.0 has been shown to impair osmoregulatory abilities and seawater tolerance of $S$. salar smolts (Staurnes et al., 1993, 1996; Kroglund \& Staurnes, 1999). When low $\mathrm{pH}($ i.e. $<6.0)$ is coupled with inorganic exchangeable aluminium $\left(\mathrm{Al}^{3+}\right)$, the resulting interaction is a synergistic effect that produces even greater physiological effects in S. salar than that of $\mathrm{pH}$ alone (Skogheim et al., 1986). Declines in growth and feeding behaviour (Magee et al., 2003), physical damage to the gill tissue (Hamilton \& Haines, 1995; Jagoe \& Haines, 1997), impaired physiological functions (Staurnes et al., 1996; Monette \& McCormick, 2008) and direct mortality (Hamilton \& Haines, 1995; Staurnes et al., 1996; Monette \& McCormick, 2008) have all been associated with the synergistic effects of low $\mathrm{pH}$ and $\mathrm{Al}^{3+}$ exposure.

In eastern Maine, experimental modifications of naturally occurring $\mathrm{pH}$ and aluminium concentrations in rivers have demonstrated negative physiological effects such as decreased plasma chloride in S. salar smolts in fresh water (Haines et al., 1990; Magee et al., 2001). Magee et al. (2003) found that wild S. salar smolts exposed to artificially acidified, aluminium-enriched, natural river water in eastern Maine's Pleasant River experienced decreased osmoregulatory capabilities in both fresh and sea water, and up to $35 \%$ mortality upon transfer to sea water. Although experimental modifications of ambient $\mathrm{pH}$ and aluminium in eastern Maine 
rivers have occurred, little is known about the extent of effects from natural water chemistries on S. salar physiology in North American rivers and streams.

In order to evaluate the magnitude of effects from natural variations in stream $\mathrm{pH}$ on $\mathrm{S}$. salar smolts, a streamside rearing study was conducted in several rivers in eastern Maine, from 2004 to 2006. In this study, only natural water chemistry was used to examine regional trends in acid-related water chemistry and the associated physiological effects in smolting $S$. salar in eastern Maine. The goal of the study was to further the scientific understanding of the effects of natural water chemistry on $S$. salar populations and to determine if there are detectable thresholds for the effect of $\mathrm{pH}$ on $S$. salar smolts in eastern Maine.

\section{MATERIALS AND METHODS}

Nine study sites in four catchments (Fig. 1) were selected. These sites represented a broad range of stream $\mathrm{pH}$ and water chemistry conditions typical of $S$. salar rivers in the U.S.A., and in particular, eastern Maine. Catchments with study sites included the Dennys River (two sites), Cathance Stream (one site), Pleasant River (two sites), Narraguagus River (one site), West Branch Narraguagus (one site), East Bear Brook (one site) and Kenduskeag Stream (one site).

At each study site, two gravity-fed 2451 circular fibreglass aquaculture tanks similar to those used in the satellite rearing studies conducted by the Atlantic Salmon Federation (Dupuis

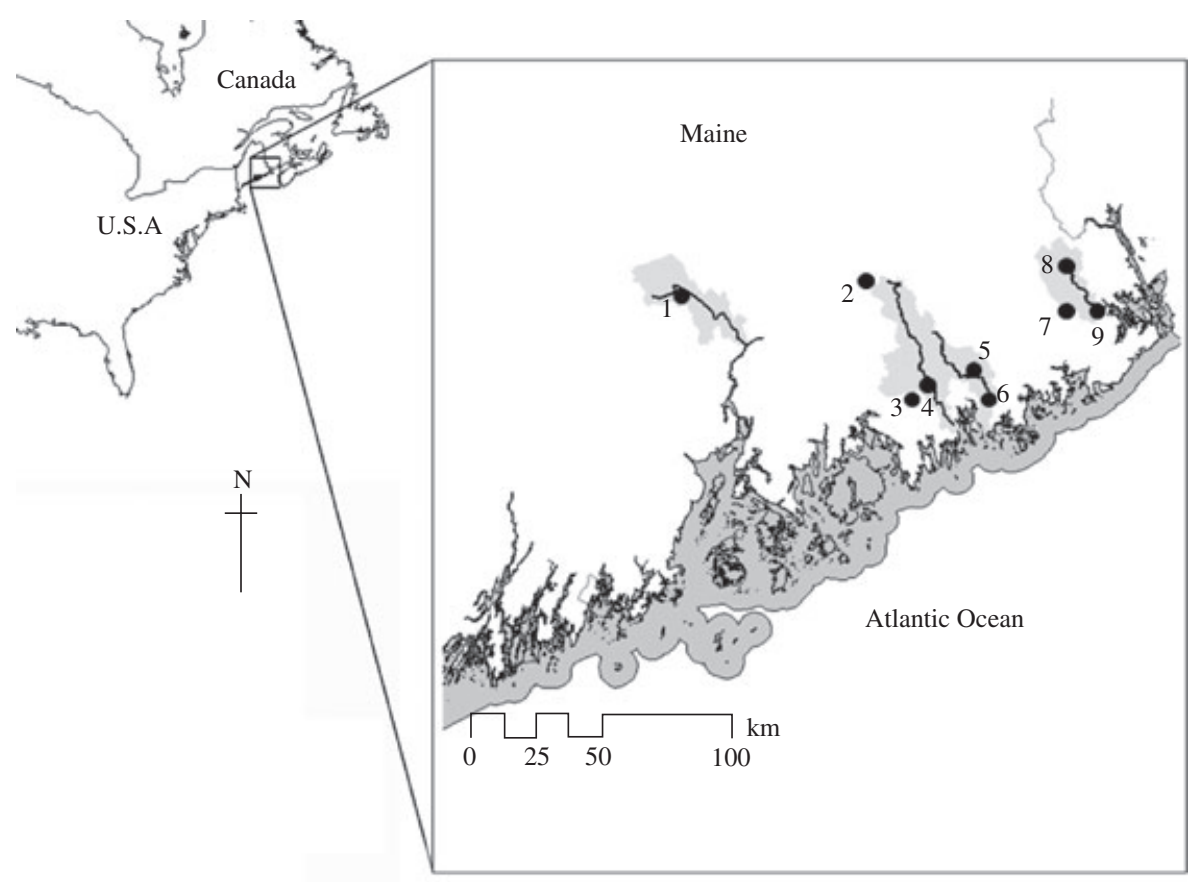

FIG. 1. Locations of catchments $(\square)$ and specific sites $(\bullet)$ used during the streamside study in eastern Maine, U.S.A., from 2004 to 2006. _ _, selected historic Salmo salar rivers; 1, Kenduskeag; 2, East Bear Brook; 3, Spragues Falls; 4, Little Falls; 5, Saco Falls; 6, Columbia Falls; 7, Cathance; 8, Meddybemps; 9, Dennysville. 
\& Dominy, 1994) were set up at the streamside. The tank inflow was via a $3.2 \mathrm{~cm}$ diameter polyethylene pipe with a nylon screened intake with an average flow rate of $51 \mathrm{~min}^{-1}$. Effluent was discharged through a screened overflow pipe into a naturally occurring basin within the flood plain in an effort to minimize any possibility of escapes.

During this study, there were two trials per year within a 21 day period between 22 April and 12 May in 2004, 2005 and 2006. This period corresponds with the normal spring S. salar smolt migrations in eastern Maine rivers (Kocik et al. 2009). Salmo salar smolts used in this study were of Penobscot River origin and obtained from the Green Lake National Fish Hatchery in Ellsworth, ME, U.S.A. One week in advance of each study period, $S$. salar smolts were isolated in a pool at the hatchery. At the start of each study period, $12 \mathrm{~S}$. salar smolts were randomly removed from the hatchery pool and anaesthetized in $100 \mathrm{mg}^{-1}$ tricaine methanesulphonate (MS-222) buffered with $100 \mathrm{mg} \mathrm{l}^{-1} \mathrm{NaHCO}_{3}$ and mixed in hatchery pool water. Once anaesthetized, $0.7 \mathrm{ml}$ blood was withdrawn from the caudal vasculature into heparinized syringes in order to measure plasma chloride and plasma glucose. Blood samples were placed immediately on wet ice. Within $10 \mathrm{~min}$ of collection, blood samples were centrifuged at $8000 \mathrm{~g}$ for $5 \mathrm{~min}$ and plasma was removed and placed in pre-labelled $0.5 \mathrm{ml}$ microcentrifuge tubes and placed immediately in dry ice. On each $S$. salar smolt, four to six gill filaments were collected from the first gill arch, just above the septum, on the left side of the fish for the measurement of $\mathrm{Na}^{+}-$and $\mathrm{K}^{+}$-ATPase activity. Samples were placed immediately into $100 \mu \mathrm{l}$ of ice cold sucrose-EDTA-imidazole (SEI) buffer $(250 \mathrm{mM}$ sucrose, $10 \mathrm{mM}$ EDTA, $50 \mathrm{mM}$ imidazole, $\mathrm{pH} 7.3$ ) in a pre-labelled $0.5 \mathrm{ml}$ microcentrifuge tube and transferred directly to dry ice. A second gill biopsy of four to six gill filaments was collected for the measurement of gill aluminium. This gill biopsy was removed, placed into an acid-washed $1.5 \mathrm{ml}$ microcentrifuge tube and transferred directly to dry ice. Upon returning to the laboratory, all physiological samples were stored at $-80^{\circ} \mathrm{C}$ until analysis. All $S$. salar smolts were lethally sampled and removed from the study population.

Salmo salar smolts for use in the field studies were transported in $113 \mathrm{l}$ coolers fitted with a recirculation aeration system and filled with water from their pool of origin at Green Lake National Fish Hatchery. Once at the study site, S. salar smolts were then transferred directly from the transport coolers to the streamside rearing tanks. Exposure periods were considered to begin upon transfer to the streamside rearing tanks, which were already flowing with ambient stream water. Each streamside rearing tank housed $12 \mathrm{~S}$. salar smolts. These S. salar smolts were continuously exposed to ambient water conditions and unfed while housed in the rearing tanks. After 3 days' exposure, six of the 12 S. salar smolts within each tank were randomly removed for sampling following the same protocol as used during the hatchery sampling. The remaining six $S$. salar smolts in each streamside rearing tank were sampled on day 6 using the same protocols. Due to high mortality rates at the East Bear Brook study site, additional rearing tanks were added at this location and $S$. salar smolts housed in the rearing tanks at this site were sampled at $24,48,72$ and $96 \mathrm{~h}$ intervals after initial exposure to ambient water conditions began. With the exception of more frequent time intervals, sampling at East Bear Brook was conducted following the same protocols as all other sites. Any smolt mortalities occurring within the streamside rearing tanks during the treatment periods were documented and deducted from that sampling period.

Water chemistry samples were collected at the hatchery and each study site during each sampling period and analysed to determine $\mathrm{pH}$, acid neutralizing capacity, calcium, sodium, magnesium, potassium, dissolved organic carbon (DOC) and total aluminium.

\section{PHYSIOLOGICAL MEASUREMENTS}

The $\mathrm{Na}^{+}$- and $\mathrm{K}^{+}$-ATPase activity was assessed following microplate assay procedures described by McCormick (1993). Gill biopsies were thawed immediately prior to assay, and $25 \mu \mathrm{l}$ of SEID $\left(0.05 \mathrm{~g}\right.$ sodium deoxycholate $\left.\mathrm{ml}^{-1} \mathrm{SEI}\right)$ added to the microcentrifuge tube with tissue and homogenized for $10-15 \mathrm{~s}$ using a Kontes pellet pestle motor. The homogenate was then centrifuged at $3200 \mathrm{~g}$ for $30 \mathrm{~s}$, and the supernatant assayed both for $\mathrm{Na}^{+}$- and $\mathrm{K}^{+}$-ATPase activity and total protein (BCA protein assay; www.piercenet.com). This kinetic assay was run at $25^{\circ} \mathrm{C}$ for $10 \mathrm{~min}$ in a temperature-controlled plate reader (www.moleculardevices.com) and read at a wavelength of $340 \mathrm{~nm}$. Gill $\mathrm{Na}^{+}-$and $\mathrm{K}^{+}$-ATPase activity was calculated as 
the difference in the production of adenosine diphosphate (ADP) in the absence and presence of $0.5 \mathrm{mM}$ ouabain and expressed as $\mu$ moles ADP $\mathrm{mg}$ protein ${ }^{-1} \mathrm{~h}^{-1}$.

Gill aluminium content was assessed following the method outlined in Teien et al. (2006) as modified by Monette \& McCormick (2008). Gill biopsies were thawed, dried at $60^{\circ} \mathrm{C}$ for $24 \mathrm{~h}$ and weighed to the nearest $0.0001 \mathrm{mg}$ using a Series 30 microbalance (Cahn Instruments, Cerritos, CA, U.S.A.). Gill biopsies were then digested by adding $98 \mu \mathrm{l}$ of $100 \%$ trace metal grade $\mathrm{HNO}_{3}$ and $2 \mu \mathrm{l}$ of $\mathrm{H}_{2} \mathrm{O}_{2}$ to biopsy tubes and heating at $100^{\circ} \mathrm{C}$ until completely evaporated (c. $3 \mathrm{~h}$ ). The same amounts of $\mathrm{HNO}_{3}$ and $\mathrm{H}_{2} \mathrm{O}_{2}$ were again added to biopsy tubes and heated with tube caps on at $60^{\circ} \mathrm{C}$ for $1 \mathrm{~h}$. Samples were diluted (9:1) by the addition of $900 \mu \mathrm{l}$ of ultrapure water, and aluminium concentration was analysed by graphite furnace atomic absorption spectrophotometer (GFAAS) as described by Monette \& McCormick (2008). A background correction was made for gill biopsy samples by subtracting the aluminium present in digestion blanks. Digestion blanks were prepared in the same way as gill biopsy tubes including transport and opening in the field, but no tissue was added. Gill aluminium was expressed as $\mu \mathrm{g} \mathrm{Al} \mathrm{g}^{-1}$ gill dry mass.

Plasma chloride was measured using a digital Buchler-Cotlove Chloridometer (Model 442-5000; www.labconco.com). Plasma glucose was measured by enzymatic coupling with hexokinase and glucose-6-phosphate dehydrogenase (Stein, 1963).

\section{WATER CHEMISTRY}

Water chemistry samples were collected from tanks concurrently with each physiological sampling event. Samples were collected in high-density polyethylene bottles prepared according to Method 1669 (USEPA, 1996) and stored on wet ice in the dark prior to analysis. After aluminium speciation, the samples were acidified with $50 \%$ trace metal grade $\mathrm{HNO}_{3}$ to a $2 \%$ concentration. Closed cell analysis of $\mathrm{pH}$ was performed according to methods outlined by USEPA 600/4-87-026 (1987) and Hillman et al. (1986) using a Thermo Scientific Orion 720Aplus ISE meter and a Ross $8104 \mathrm{BN}$ pH probe which was calibrated with U.S. National Institute of Standards and Technology (NIST) traceable low ionic strength Thermo Scientific Orion Pure Water pH buffers in pH 4.10 and 6.97 (www.thermoscientific.com). Acid neutralizing capacity (ANC) was measured with an ABU 90 Radiometer titrator system (USEPA 600/4-87-026, 1987; Hillman et al., 1986). A two-channel ion chromatograph was used to determine calcium $(\mathrm{Ca})$, sodium $(\mathrm{Na})$, magnesium $(\mathrm{Mg})$ and potassium $(\mathrm{K})$ content (ASTM, 2003). An OI analytical 1010 carbon analyser was used to determine DOC content by heated persulphate oxidation (USEPA 600/4-79-020, 1983) and a Perkin Elmer 600 GFAAS (www.perkinelmer.com) was used for aluminium measurements (USEPA 600/R-93100, 1993). All water chemistry samples were processed at the Senator George J. Mitchell Center for Environmental and Watershed Research, University of Maine, Orono, ME, U.S.A.

\section{STATISTICS}

In order to determine if the different stream chemistries affected the physiology of $S$. salar smolts, a three-way ANOVA of trial (two trials in each of 3 years), day of sampling ( 3 or 6 ) and location (site) were conducted. If location was significant, the data were further analysed for a relationship between $\mathrm{pH}$ and the physiological response of $S$. salar smolts using a nonlinear mixed model (SAS procedure NLMIXED; www.sas.com) to identify break points in correlations of $S$. salar smolt physiology and water chemistry. The NLMIXED procedure was chosen because it included an estimated parameter for the break point, or changepoint, of the segmented fit to the data that cannot be written as a general linear model and because the mixed models capabilities allowed for the inclusion of random sampling location effects in the model. NLMIXED analyses in SAS use a dual quasi-Newton optimization technique with an adaptive Gaussian quadrature integration method. Breakpoint estimates identified through the NLMIXED procedure are assumed to represent thresholds at which changes in physiological response to ambient conditions were most significant and therefore indicate the point at which ambient conditions may have the potential for negative physiological effects. Data from East Bear Brook were excluded from the non-linear mixed models due to the extreme difference in both water chemistry and physiological response of S. salar smolts 
exposed to this system. Separate analyses were conducted to assess the study site at East Bear Brook relative to other study locations in eastern Maine.

Comparisons of S. salar smolt physiology at the East Bear Brook site were conducted using a one-way ANOVA followed by least significant difference (LSD) multiple range tests (Statgraphics Centurion v15; www.statgraphics.com). These methods allowed for the identification of significant difference in physiological response among exposure times as well as the capability to formulate relative comparisons within and among study sites. Pearson's productmoment (linear) correlation $(r)$ was used to examine the relationship between individual water chemistry variables and physiological responses.

\section{RESULTS}

\section{STREAM CHEMISTRY AND PHYSIOLOGICAL RESPONSE}

Study site $\mathrm{pH}$ ranged from 5.0 to 7.5 (Fig. 2), total water aluminium content from 11 to $222 \mu \mathrm{g} \mathrm{l}^{-1}$ and DOC content from $4 \cdot 3$ to $15.5 \mathrm{mg} \mathrm{l}^{-1}$. In 2004 and 2006 , $\mathrm{pH}$ typically remained $>6 \cdot 0$, but in 2005 , coincident with increased rainfall, $\mathrm{pH}$ dropped to $<6.0$ at several sites. The mean water chemistry variables from each site are shown in Table I. There was a significant correlation of most water chemistry variables with one another (Table II). There were no mortalities in any of the streamside tanks, except for East Bear Brook which was analysed separately because of its distinct water chemistry. Fish in two locations with low $\mathrm{pH}$ in 2005 , however, were unresponsive to external stimuli after 6 days of exposure.

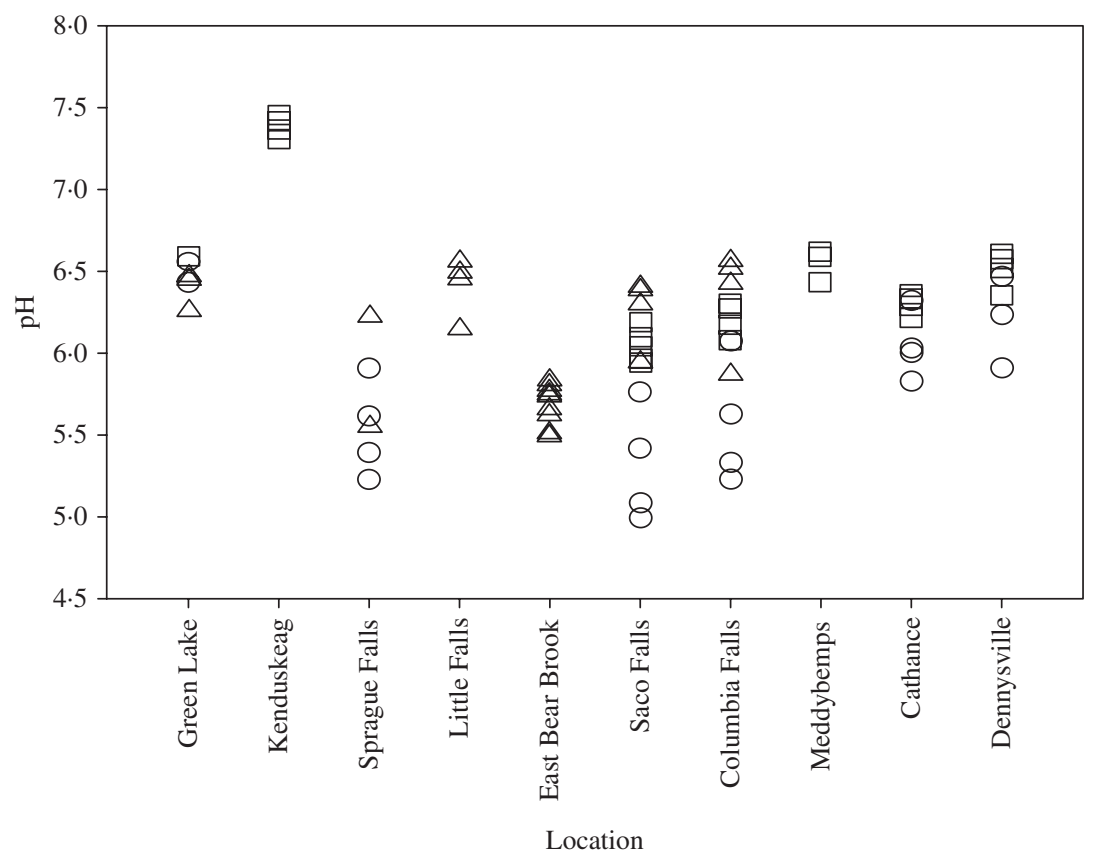

FIG. 2. Stream pH measurement collected at eastern Maine, study sites at which Salmo salar smolts were held in $2004(\square), 2005(\bigcirc)$ and $2006(\Delta)$. 


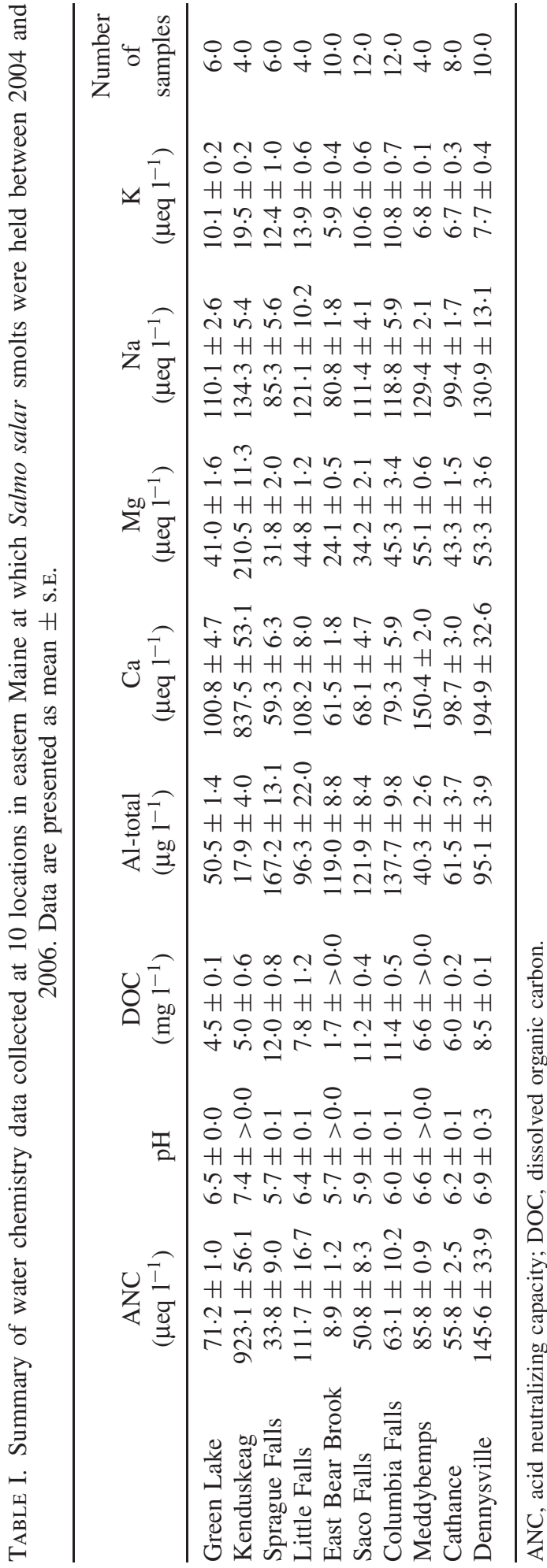




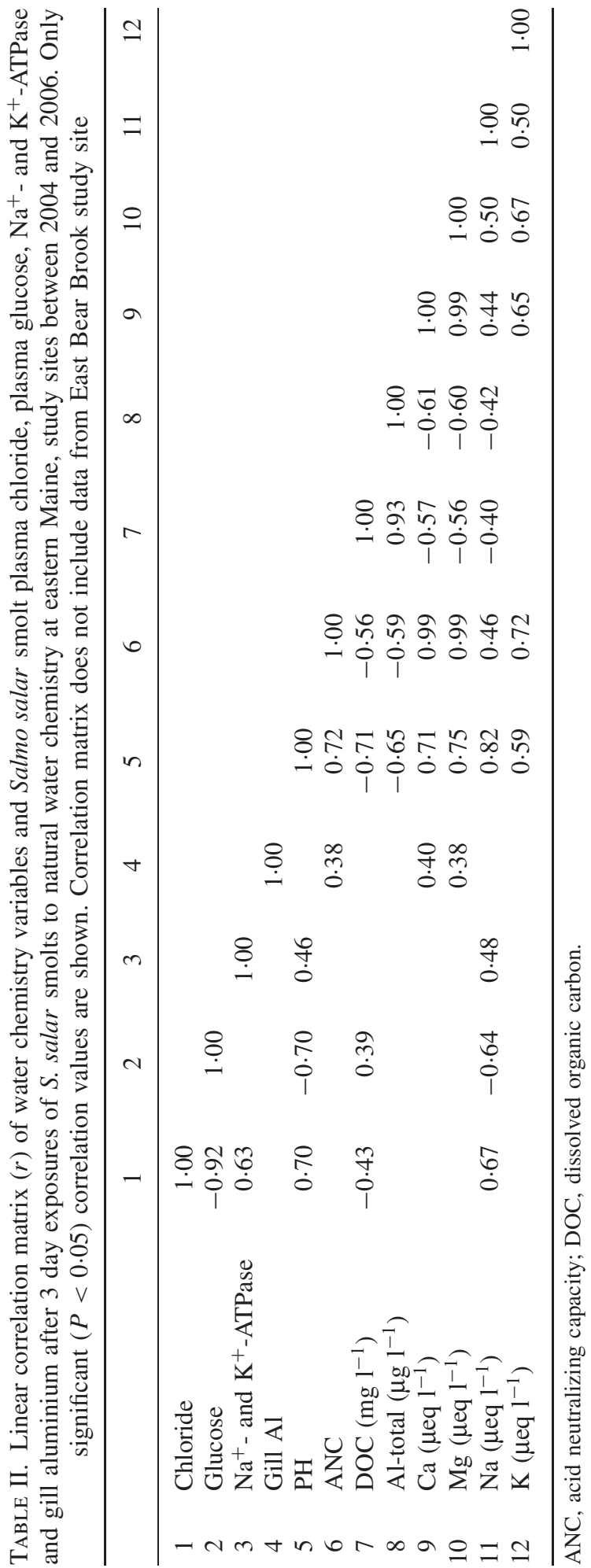


There was a significant effect of location (stream where fish were held) and trial (two trials during each of 3 years) on plasma chloride and glucose (three-way ANOVA, $P<0.001$ ), but no effect of day of sampling (3v.6). Gill $\mathrm{Na}^{+}-$and $\mathrm{K}^{+}$ATPase activity varied substantially within and among study sites, and there was no significant effect of location, trial or sampling day. There was a significant effect of location on gill aluminium, but no effect of trial or day of sampling (three-way ANOVA, $P>0 \cdot 05)$.

There was a significant correlation between plasma chloride and plasma glucose with $\mathrm{pH}, \mathrm{DOC}$ and sodium (Table II). Gill $\mathrm{Na}^{+}$- and $\mathrm{K}^{+}$-ATPase activity was positively correlated with $\mathrm{pH}$ and sodium. There was no significant correlation between gill aluminium and any of the water chemistry variables measured. Plasma chloride, glucose and gill $\mathrm{Na}^{+}$- and $\mathrm{K}^{+}$-ATPase activity were significantly correlated with one another, but not with gill aluminium.

There were significant correlations among most of the water chemistry variables, and it was therefore not appropriate to use stepwise regression or similar analyses to determine the relative importance of these variables on physiological responses. Because the strongest correlation of plasma chloride and plasma glucose was with $\mathrm{pH}$, and that previous research has established a relationship between low $\mathrm{pH}$ and physiological impact on $S$. salar smolts, the relationship of $\mathrm{pH}$ and these variables was analysed further. Although there was a significant correlation of gill $\mathrm{Na}^{+}-$and $\mathrm{K}^{+}$-ATPase activity and $\mathrm{pH}$, this relationship was not graphically or statistically analysed because the correlation was relatively weak and a significant effect of location on this variable had not been found.

Graphic analysis indicated a possible break or transition point in the effect of $\mathrm{pH}$ on both plasma chloride and plasma glucose. Coefficient estimates for the break points in physiological response at $\mathrm{pH}$ for $S$. salar smolts exposed to ambient conditions differed between plasma chloride and plasma glucose as well as 3 and 6 day exposure periods (Fig. 3). The breakpoint estimate using the NLMIXED model for plasma chloride after a 3 day exposure to ambient conditions was $136.0 \pm 1.4$ (mean \pm S.E.; $P<0.001$ ) at pH $5.9 \pm 0.1$ (mean \pm s.E.; $P<0.001$ ) with a slope estimate of 22.1 for values below this breakpoint estimate (Table III). The breakpoint estimate for plasma chloride after a 6 day exposure to ambient conditions was $136 \cdot 0 \pm 2.5$ (mean \pm S.E.; $P<0.001)$ at $\mathrm{pH} 5.7 \pm 0.1$ (mean \pm S.E.; $P<0.001$ ) with a slope estimate of 58.5 for values below this breakpoint estimate (Table III).

Plasma glucose had a breakpoint estimate of $8.5 \pm 0.7$ (mean \pm s.E.; $P<0.001$ ) at $\mathrm{pH} 5.5 \pm 0.1$ (mean \pm S.E.; $P<0.001$ ) and a slope estimate of -18.14 for values below this breakpoint estimate after this same 3 day exposure (Table III). The breakpoint estimate for plasma glucose after a 6 day exposure to ambient conditions was $7.3 \pm 0.6$ (mean \pm S.E.; $P<0.001)$ at $\mathrm{pH} 5.7 \pm 0.1$ (mean \pm S.E.; $P<0.001)$ with a slope estimate of $-27 \cdot 3$ for values below this break point (Table III).

\section{EAST BEAR BROOK}

The $\mathrm{pH}$ in East Bear Brook ranged from $5 \cdot 6$ to 5.8, total water aluminium levels ranged from 81 to $173 \mu \mathrm{g}^{-1}$ and DOC content ranged from 1.5 to $1.9 \mathrm{mg} \mathrm{l}^{-1}$. Gill $\mathrm{Na}^{+}$- and $\mathrm{K}^{+}$-ATPase activity at East Bear Brook did not change over time compared to the control samples (d.f. $=3,87, P>0.05$ ). A decline in mean values, however, was observed in fish exposed to East Bear Brook when compared with 

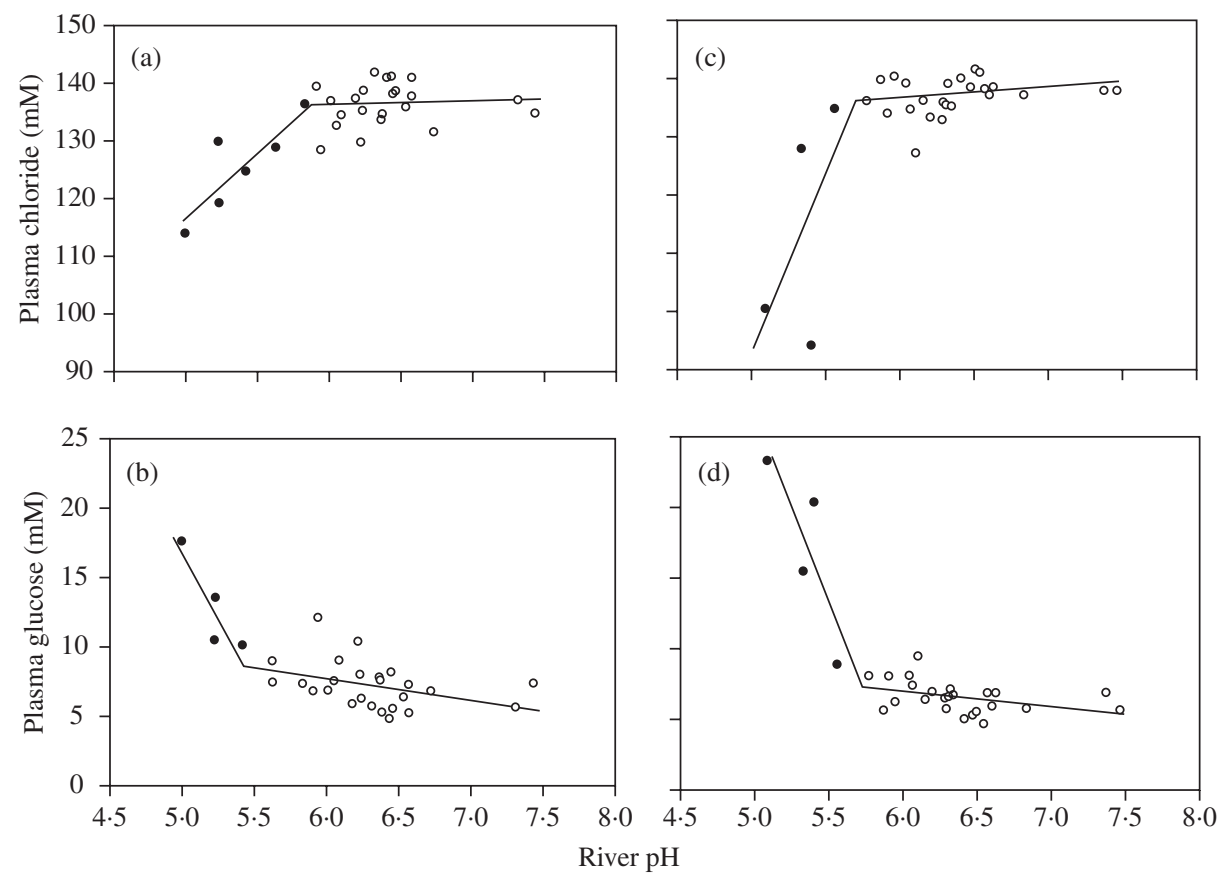

FIG. 3. Physiological response in (a), (c) plasma chloride and (b), (d) plasma glucose of Salmo salar smolts exposed to ambient water chemistry conditions at various study sites throughout eastern Maine, for (a), (b) physiological response of $S$. salar smolts after a 3 day and (c), (d) 6 day exposure to ambient stream $\mathrm{pH}$. The estimated changepoint $(O)$ or break point $(\bullet)$ in physiological response of $S$. salar smolts to stream $\mathrm{pH}$ are illustrated. Each point is the mean of 12 individuals sampled from two replicate tanks (see Table III).

the control site. Mean \pm S.D. values for gill $\mathrm{Na}^{+}$- and $\mathrm{K}^{+}$-ATPase activity were $14.3 \pm 3.4$ at initial sampling site $(n=35), 13.7 \pm 2.3$ at $24 \mathrm{~h}(n=36), 12.5 \pm 2.7$ at $48 \mathrm{~h}(n=31), 12.7 \pm 2.4$ at $72 \mathrm{~h}(n=18)$ and $12.4 \pm 2.0$ at $96 \mathrm{~h}(n=2)$.

Plasma chloride samples collected at East Bear Brook were $\log _{10}$ transformed and varied over time compared to the control samples (d.f. $=3,89, P<0.001$ ). Plasma chloride values of East Bear Brook fish were lower than control fish within $24 \mathrm{~h}$ and showed another decline between 24 and $48 \mathrm{~h}$ exposure. Longer exposure time to East Bear Brook did not cause plasma chloride to decline beyond the measurements taken after $48 \mathrm{~h}$ exposure (Fig. 4).

Plasma glucose at East Bear Brook increased over time compared to the control samples (d.f. $=3,89, P<0 \cdot 001$ ). Plasma glucose values of East Bear Brook fish were elevated within $24 \mathrm{~h}$ and continued to increase between 48 and $72 \mathrm{~h}$ exposure (Fig. 4).

Gill aluminium samples collected at East Bear Brook increased over time compared to the control samples (d.f. $=3,76, P<0 \cdot 001$ ). Gill aluminium values of East Bear Brook fish increased within $24 \mathrm{~h}$. No additional increases occurred after $24 \mathrm{~h}$ exposure (Fig. 5).

Unlike other study sites, mortality of S. salar smolts did occur at East Bear Brook and after 3 days of exposure S. salar smolt mortalities reached $40 \%$ and 
TABLE III. Results from non-linear mixed model analyses (NLMIXED) of $\mathrm{pH}$ and Salmo salar smolt plasma chloride and plasma glucose after 3 and 6 day exposures of $S$. salar smolts to ambient river conditions at nine eastern Maine, study sites. Model output does not include data from the East Bear Brook study site

\begin{tabular}{|c|c|c|c|c|c|}
\hline & Variable & Breakpoint estimate \pm S.E. & d.f. & $t$-value & $P$ \\
\hline \multirow[t]{6}{*}{3 day exposure } & $\mathrm{pH}$ & $5 \cdot 87 \pm 0 \cdot 14$ & 7 & $42 \cdot 15$ & $<0 \cdot 001$ \\
\hline & Chloride & $135.89 \pm 1.40$ & 7 & $97 \cdot 39$ & $<0.001$ \\
\hline & Slope & $22 \cdot 14 \pm 5.06$ & 7 & $4 \cdot 38$ & $<0 \cdot 01$ \\
\hline & $\mathrm{pH}$ & $5.47 \pm 0.09$ & 7 & $57 \cdot 57$ & $<0.001$ \\
\hline & Glucose & $8.47 \pm 0.74$ & 7 & 11.41 & $<0.001$ \\
\hline & Slope & $-18 \cdot 15 \pm 5 \cdot 01$ & 7 & -3.63 & $<0 \cdot 01$ \\
\hline \multirow{6}{*}{6 day exposure } & $\mathrm{pH}$ & $5 \cdot 71 \pm 0.14$ & 7 & $42 \cdot 19$ & $<0.001$ \\
\hline & Chloride & $135 \cdot 82 \pm 2 \cdot 46$ & 7 & $55 \cdot 15$ & $<0 \cdot 001$ \\
\hline & Slope & $58.50 \pm 18.03$ & 7 & $3 \cdot 25$ & $<0 \cdot 05$ \\
\hline & $\mathrm{pH}$ & $5 \cdot 70 \pm 0.07$ & 7 & 85 & $<0 \cdot 001$ \\
\hline & Glucose & $7.33 \pm 0.59$ & 7 & $12 \cdot 37$ & $<0.001$ \\
\hline & Slope & $-27 \cdot 34 \pm 4 \cdot 24$ & 7 & $-6 \cdot 45$ & $<0.001$ \\
\hline
\end{tabular}

continued to increase through to day 4, at which point all remaining fish were sampled (Fig. 4). A comparison of East Bear Brook to other eastern Maine study sites at $72 \mathrm{~h}$ exposure (Fig. 6) showed that total water aluminium levels at East Bear Brook $\left(95 \cdot 8-109.2 \mu \mathrm{g} \mathrm{1^{-1 }}\right)$ were within the observed range at other study

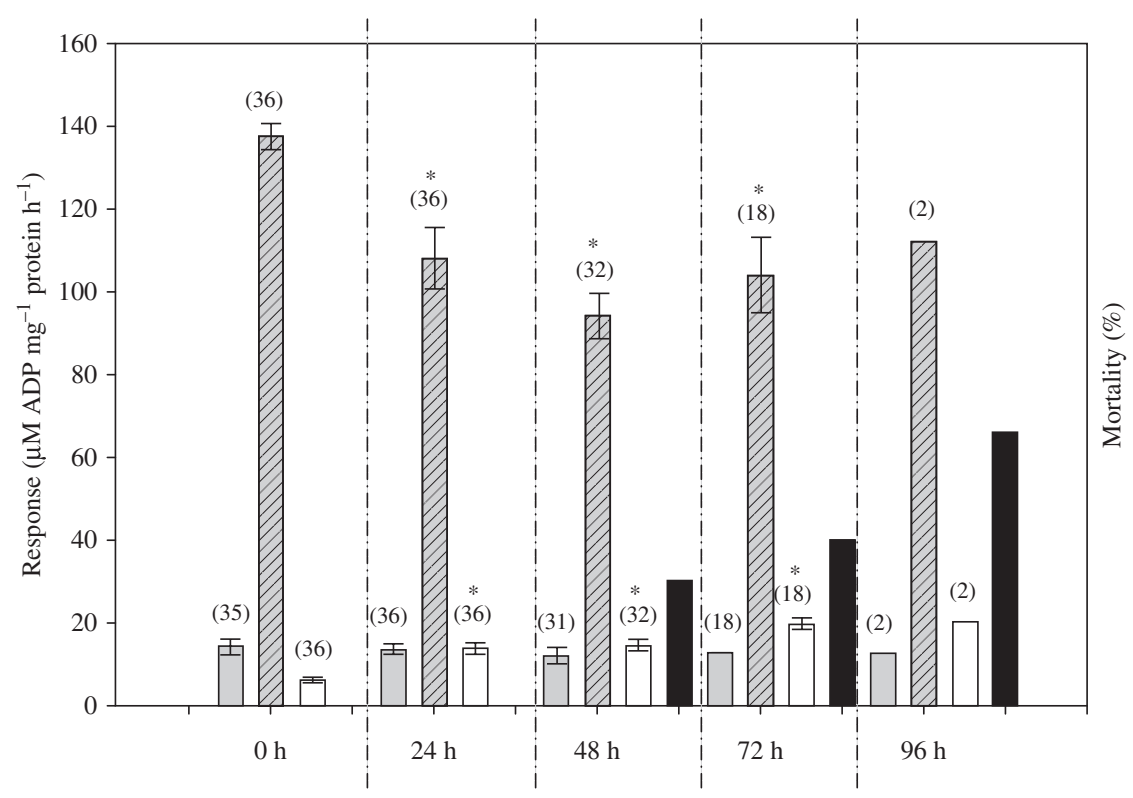

FIG. 4. Physiological response of Salmo salar smolts exposed to ambient water chemistry conditions at East Bear Brook, eastern Maine, during spring 2006: $\mathrm{Na}^{+}$- and $\mathrm{K}^{+}$-ATPase ( $\mu \mathrm{M}$ ADP $\mathrm{mg}^{-1} \operatorname{protein~}^{-1}$ ) $(\square)$, plasma chloride $(\square)$ and plasma glucose $(\mu$ mole) $(\square)$ and mortality $(\%)(\square)$. Values are mean \pm S.D. Sample size is given in parentheses above each bar. *, a significant statistical difference $(P<0 \cdot 05)$ when compared with $0 \mathrm{~h}$. 


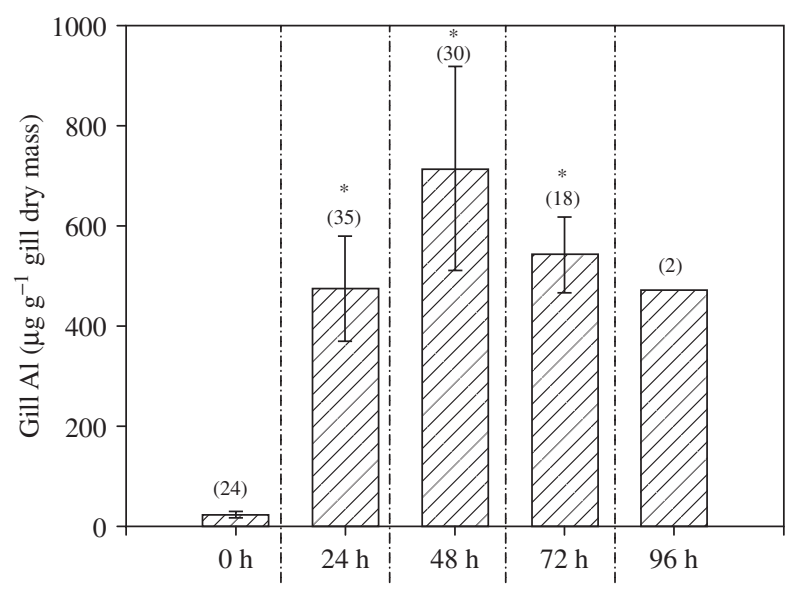

FIG. 5. Gill aluminium concentrations of Salmo salar smolts exposed to ambient conditions at East Bear Brook, eastern Maine, during the 2006. Values are mean \pm S.D. Sample size is given in parentheses above each bar. *, a significant statistical difference $(P<0.05)$ when compared with $0 \mathrm{~h}$.

sites (79.9-162.1 $\mathrm{gg}^{-1}$ ) with similar $\mathrm{pH}$. Additionally, East Bear Brook had DOC concentrations $<1.9 \mathrm{mg} \mathrm{l}^{-1}$ whereas the other study sites were all $>4.23 \mathrm{mg} \mathrm{l}^{-1}$. The observed mortality rate of $S$. salar smolts exposed to East Bear Brook was $40 \%$ whereas no smolt mortality was observed at other sites with similar $\mathrm{pH}$ and aluminium concentrations. Salmo salar smolts exposed to East Bear Brook often appeared dark in colouration and at times were either slow to respond, or unresponsive, to human presence near the tanks.

\section{DISCUSSION}

The results of this study suggest that the physiological responses of $S$. salar smolts to water chemistry conditions in eastern Maine are variable but can be reliably predicted under certain conditions. Negative physiological effects are strongly correlated to $\mathrm{pH}$ and can occur rapidly (within days) under natural conditions that exist in some rivers in the north-eastern U.S.A. Additionally, the results suggest that $S$. salar smolts utilizing rivers and streams in eastern Maine with low DOC concentrations are probably more vulnerable to aluminium toxicity during low $\mathrm{pH}$ events than $S$. salar smolts residing in streams with moderate to high concentrations of DOC.

This study found that plasma chloride and plasma glucose levels in S. salar smolts exposed to natural water chemistries were strongly correlated to $\mathrm{pH}$. The use of these indicators of physiological stress allowed $\mathrm{pH}$ thresholds at which $S$. salar smolts showed negative physiological response to ambient river conditions in eastern Maine to be estimated. As expected, plasma chloride content decreased and plasma glucose content increased as $\mathrm{pH}$ declined. These results are consistent with laboratory studies demonstrating that $\mathrm{pH}>c .6 .0$ is not harmful to $S$. salar smolts (Staurnes et al., 1995; Monette \& McCormick, 2008), as well as previous studies conducted in Norway and Nova Scotia where acid-related physiological effects in S. salar have been documented (Lacroix \& Townsend, 1987; Staurnes et al., 1996). The absence of 


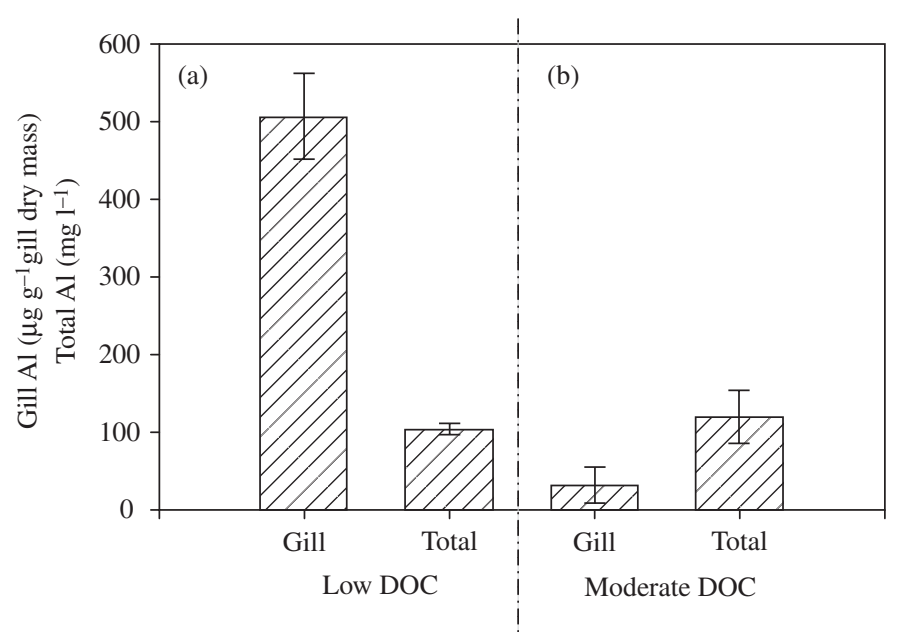

FIG. 6. Comparison of Salmo salar smolt gill aluminium after $72 \mathrm{~h}$ exposures to (a) East Bear Brook, eastern Maine, with low dissolved organic carbon (DOC) stream water and to (b) other eastern Maine study sites with similar $\mathrm{pH}$ and similar levels of total water aluminium but moderate DOC. A $40 \%$ mortality rate of S. salar smolts was observed under the conditions present at East Bear Brook, whereas no mortality was observed at the other sites. Values are the means \pm S.D. of three exposure periods at East Bear Brook and five exposure periods at the other sites consisting of at least 12 fish per exposure.

increased gill aluminium at sites other than East Bear Brook suggests the possibility that these physiological effects are due primarily to the influence of low $\mathrm{pH}$ and independent of aluminium. The possibility that aluminium played a role cannot be ruled out, despite the fact gill aluminium in these streams was found not to be a reliable indicator of aluminium toxicity. In East Bear Brook where DOC was low, gill aluminium did appear to be a reliable indicator of more severe physiological responses.

The study also revealed that gill $\mathrm{Na}^{+}-$and $\mathrm{K}^{+}$-ATPase activity did not differ in response to stream location, in spite of significant variation in stream $\mathrm{pH}$. This may in part be due to the high variability of up to $50 \%$ in gill $\mathrm{Na}^{+}-$and $\mathrm{K}^{+}$-ATPase activity among individual $S$. salar smolts. When mean values of gill $\mathrm{Na}^{+}-$and $\mathrm{K}^{+}$ATPase activity were assessed, there was a significant relationship with stream $\mathrm{pH}$ and with plasma chloride and glucose. In a laboratory study in which $S$. salar smolts were exposed to acid and aluminium for 6 days, there were significant effects on plasma ions, plasma glucose and salinity tolerance, without significant effects on gill $\mathrm{Na}^{+}$- and $\mathrm{K}^{+}$-ATPase activity (Monette et al., 2010). These results contrast with many longer term studies which have found decreased gill $\mathrm{Na}^{+}$- and $\mathrm{K}^{+}$ATPase activity in $S$. salar smolts exposed to low $\mathrm{pH}$. Measurement of gill $\mathrm{Na}^{+}$ and $\mathrm{K}^{+}$-ATPase activity employed in the present study provides a measure of the total potential enzyme activity, which is usually reflective of total abundance of the enzyme. It is therefore possible that acid and aluminium could be affecting the in situ activity of the enzyme (and thus affecting ion transport) without affecting the gill $\mathrm{Na}^{+}$- and $\mathrm{K}^{+}$-ATPase activity. Another possibility is that the freshwater and seawater isoforms of $\mathrm{Na}^{+}$- and $\mathrm{K}^{+}$-ATPase that have recently been found in $S$. salar gill tissue (McCormick et al., 2009a) may respond differently to acid and aluminium exposure and would not be detected by the measurement of gill $\mathrm{Na}^{+}$- and $\mathrm{K}^{+}$-ATPase 
activity. In any event, the lack of response of gill $\mathrm{Na}^{+}$- and $\mathrm{K}^{+}$-ATPase activity at $\mathrm{pH}$ levels that affect plasma chloride suggests that this measurement may not consistently reflect physiological responses in $S$. salar smolts in short-term exposure to acid and aluminium.

It is clear that factors other than just $\mathrm{pH}$ are affecting physiological responses of $S$. salar smolts. This was shown by the differences in physiological response of S. salar smolts to water chemistry at East Bear Brook in comparison to the other eastern Maine study sites. At East Bear Brook and several other sites such as Columbia, Saco and Sprague Falls, $\mathrm{pH}$ and total aluminium were similar whereas DOC was much lower at East Bear Brook. The most likely explanation is that the reduced DOC at the East Bear Brook study site led to decreased organic-aluminium complexes, increasing the total amount of toxic inorganic aluminium. In a previous study of eastern Maine rivers, Haines et al. (1990) found that streams with DOC averaging $3.5 \mathrm{mg} \mathrm{l}^{-1}$ had inorganic aluminium averaging $40 \mu \mathrm{g} \mathrm{l}^{-1}$, while streams with DOC averaging $10 \mathrm{mg} \mathrm{l}^{-1}$ had half the levels of inorganic aluminium. On the basis of the known toxic thresholds of inorganic aluminium on $S$. salar smolts (Kroglund et al., 2007), this two-fold increase in inorganic aluminium is likely to have negative consequences whenever $\mathrm{pH}$ is $<6 \cdot 0$. It should be noted, however, that the control of inorganic aluminium is highly complex and dependent on the interaction of many aspects of stream chemistry. Reduced $\mathrm{pH}$ can both increase the amount of aluminium that is dissolved from soil into water and increase its toxicity (Rosseland et al., 1990). Inorganic aluminium and especially pH vary strongly with changes in discharge, whereas DOC is less responsive to flow (Haines et al., 1990). The concentration of cations and anions, especially fluoride, also play a role in determining the concentration of inorganic aluminium. Although the possibility that other chemical constituents played a role in the results of the study at East Bear Brook cannot be ruled out, it seemed most likely that low DOC and low $\mathrm{pH}$ played the primary role in promoting aluminium toxicity based on the elevated gill aluminium measured in $S$. salar smolts exposed to stream water at this site. Thus, the present results support the idea that interactions between aluminium and DOC constitute an important mechanism in reducing the toxic effects of $\mathrm{pH}$ and aluminium on fishes in natural waters (Neville, 1985; Roy \& Campbell, 1997).

Salmo salar smolts exposed to East Bear Brook, which is more representative of many southern Norwegian rivers (e.g. low pH, high aluminium and low DOC) where stream acidification is known to affect $S$. salar smolt survival, experienced a rapid loss of plasma chloride, a rapid increase in plasma glucose, significantly higher gill aluminium content and mortality. East Bear Brook was the only study site where S. salar smolts suffered direct mortality. The observed mortality which occurred in S. salar smolts exposed to East Bear Brook is thought to be a result of elevated inorganic aluminium concentrations in the brook.

As previously mentioned, aluminium is very dynamic in aquatic environments, its speciation can be strongly influenced by $\mathrm{pH}$ and it can affect $S$. salar smolts by disrupting normal gill functions and affecting both osmoregulation and respiration (Gensemer \& Playle, 1999). Elevated gill aluminium concentrations (323-1011 $\mu \mathrm{g} \mathrm{g}^{-1}$ ) measured in S. salar smolts at the East Bear Brook study site are believed to be a result of the increased availability of inorganic aluminium under low $\mathrm{pH}$, high aluminium and low DOC conditions occurring in East Bear Brook during this study. These elevated gill aluminium concentrations appear to be responsible 
for the physiological impairment and subsequent mortalities of $S$. salar smolts at this study site. In support of this hypothesis is a study conducted by McCormick et al. $(2009 b)$ in which gill aluminium was found to be a strong predictor of both physiological stress and mortality of $S$. salar smolts exposed to similar water chemistries in southern New England.

Although salinity tolerance was not assessed in this study, previous studies have shown that S. salar smolts lose salinity tolerance when exposed to acid and aluminium at levels similar to those in the present study (Saunders et al., 1983; Kroglund \& Finstad, 2003; Kroglund et al., 2007). Previous studies have also shown when plasma chloride of $S$. salar smolts is decreased to the levels seen in the present study (e.g. $<110 \mathrm{mM}$ ), salinity tolerance is also lost (Kroglund et al., 2007; Monette et al., 2010). In the present study, $S$. salar smolts exposed to ambient conditions of episodically acidified eastern Maine rivers experienced reduced plasma chloride when $\mathrm{pH}$ fell to $<5.9$, and the severity of the physiological stress increased with further declines in $\mathrm{pH}$. Thus, in years when episodic acidification events are sufficient to result in $\mathrm{pH}$ reduction $<5.9$ that leads to loss of plasma chloride, accompanying physiological responses will probably result in the loss of salinity tolerance of S. salar smolts. Such a loss in salinity tolerance has been shown to result in reduced ocean survival (Kroglund et al., 2007), threatening the longer term sustainability of S. salar populations.

In conclusion, the findings from this study suggest that the negative physiological effects observed in $S$. salar smolts exposed to ambient water chemistries at the study sites can result from either the individual or combined effects of $\mathrm{pH}$ and instream inorganic aluminium. The findings from this study, and supporting literature, suggest that the presence of moderate to high DOC concentrations may be buffering the potentially lethal effects of inorganic aluminium on $S$. salar smolts at several of the study sites more typical of the natural water chemistries found in Nova Scotia (i.e. low $\mathrm{pH}$, high aluminium and moderate to high DOC). Therefore, it appears that the current level of DOC in many eastern Maine rivers is protective to some degree of the negative physiological responses typically associated with low $\mathrm{pH}$ and high aluminium concentrations. This is demonstrated by lower gill aluminium concentrations in $S$. salar smolts exposed to high DOC waters relative to S. salar smolts exposed to low DOC waters with similar $\mathrm{pH}$ and aluminium concentrations. It is important to note, however, that when $\mathrm{pH}$ drops to $<6.0$ coincident with $S$. salar smolt migration, physiological compromise of $S$. salar smolts can occur under certain conditions found in eastern Maine rivers (e.g. low $\mathrm{pH}$, high aluminium and low DOC) and could have negative consequences for their marine survival.

We thank M. O'Dea, M. Monette and A. Regish for their help in running physiological assays. We also thank M. Hachey for his assistance with data collection and M. Cooperman for additional assistance with data analysis. Additionally, we would like to thank U.S. National Oceanographic and Atmospheric Administration's National Marine Fisheries Services Northeast Regional Office and Science Center as well as the U.S. Geological Survey Conte Anadromous Fish Research Center for funding this research, U.S. Fish and Wildlife Service Green Lake and Craig Brook National Fish Hatcheries for providing juvenile salmon, Maine Department of Marine Resources (formerly Atlantic Salmon Commission) for assisting with site selection, the Downeast Salmon Federation and Dennys Salmon Club for allowing access to their property, and the University of Maine's Sawyer Environmental Chemistry Lab and Senator George J. Mitchell Center for Environmental and Watershed Research for their assistance with water chemistry analyses. 


\section{References}

ASTM (2003). Standard test method for determination of dissolved alkali and alkaline earth cations and ammonium in water and wastewater by ion chromatography. Annual Book of ASTM Standards 11.01.

Baum, E. (1997). Maine Atlantic Salmon, A National Treasure. Hermon, ME: Atlantic Salmon Unlimited.

Bjerknes, V., Fyllingen, I., Holtet, L., Teien, H. C., Rosseland, B. O. \& Kroglund, F. (2003). Aluminium in acidic river water causes mortality of farmed Atlantic salmon (Salmo salar L.) in Norwegian fjords. Marine Chemistry 83, 169-174.

Clegg, M. T., Barten, P. K., Fleming, I. A., Gross, M. R., Incze, L. S., Kapuscinksi, A. R., O'Brien, P., Neis, B., Ryman, N., Smouse, P. E., Specker, J. L., Stickney, R. R. \& Sutinen, J. G. (2004). Atlantic Salmon in Maine. Washington, DC: The National Academies Press.

Dupuis, T. \& Dominy, L. (1994). Introduction to Satellite Rearing Installation and Operation Manual. St Andrews, NB: Atlantic Salmon Federation.

Gensemer, R. W. \& Playle, R. C. (1999). The bioavailability and toxicity of aluminum in aquatic environments. Critical Reviews in Environmental Science and Technology 29, $315-450$.

Haines, T. A. (1981). Acidic precipitation and its consequences for aquatic ecosystems: a review. Transactions of the American Fisheries Society 110, 669-707.

Haines, T. A., Norton, S. A., Kahl, J. S., Fay, C. W., Pauwels, S. J. \& Jagoe, C. H. (1990). Intensive Studies of Stream Fish Populations in Maine. Washington, DC: Environmental Protection Agency.

Hamilton, S. J. \& Haines, T. A. (1995). Influence of fluoride on aluminum toxicity to Atlantic salmon (Salmo salar). Canadian Journal of Fisheries and Aquatic Sciences 52, $2432-2444$.

Hesthagen, T. \& Hansen, L. P. (1991). Estimates of the annual loss of Atlantic salmon (Salmo salar L.) in Norway due to acidification. Aquaculture and Fisheries Management 22, $85-91$.

Hillman, D. C., Potter, J. \& Simon, S. (1986). Analytical methods for the National Surface Water Survey, Eastern Lake Survey. EPA/600/4-86/009. Las Vegas, NV: United States Environmental Protection Agency.

Jagoe, C. H. \& Haines, T. A. (1997). Changes in gill morphology of Atlantic salmon (Salmo salar) smolts due to addition of acid and aluminum to stream water. Environmental Pollution 97, 137-146.

Kahl, J. S., Norton, S. A., Haines, T. A., Rochette, E. A., Heath, R. H. \& Nodvin, S. C. (1992). Mechanisms of episodic acidification in low-order streams in Maine, USA. Environmental Pollution 78, 37-44.

Kocik, J. F., Hawkes, J. P., Sheehan, T. F., Music, P. A. \& Beland, K. F. (2009). Assessing estuarine and coastal migration and survival of wild Atlantic salmon smolts from the Narraguagus River, Maine using ultrasonic telemetry. American Fisheries Society Symposium 69, 293-310.

Kroglund, F. \& Finstad, B. (2003). Low concentrations of inorganic monomeric aluminum impair physiological status and marine survival of Atlantic salmon. Aquaculture 222, $119-133$.

Kroglund, F. \& Staurnes, M. (1999). Water quality requirements of smolting Atlantic salmon (Salmo salar) in limed acid rivers. Canadian Journal of Fisheries and Aquatic Sciences 56, 2078-2086.

Kroglund, F., Kaste, O., Rosseland, B. O. \& Poppe, T. (2001). The return of the salmon. Water, Air, and Soil Pollution 130, 1349-1354.

Kroglund, F., Finstad, B., Stefansson, S. O., Nilsen, T. O., Kristensen, T., Rosseland, B. O., Teien, H. C. \& Salbu, B. (2007). Exposure to moderate acid water and aluminum reduces Atlantic salmon post-smolt survival. Aquaculture 273, 360-373.

Lacroix, G. L. \& Townsend, D. R. (1987). Responses of juvenile Atlantic salmon (Salmo salar) to episodic increases in acidity of Nova Scotia rivers. Canadian Journal of Fisheries and Aquatic Sciences 44, 1475-1484. 
Leivestad, H., Jensen, E., Kjartansson, H. \& Xingfu, L. (1987). Aqueous speciation of aluminum and toxic effects on Atlantic salmon. Annuals of the Royal Belgian Society for Zoology 117 (Suppl. 1), 387-398.

Magee, J. A., Haines, T. A., Kocik, J. F., Beland, K. F. \& McCormick, S. D. (2001). Effects of acidity and aluminum on the physiology and migratory behavior of Atlantic salmon smolts in Maine, USA. Water, Air and Soil Pollution 130, 881-886.

Magee, J. A., Obedzinski, M., McCormick, S. D. \& Kocik, J. F. (2003). Effects of episodic acidification on Atlantic salmon (Salmo salar) smolts. Canadian Journal of Fisheries and Aquatic Sciences 60, 214-221.

McCormick, S. D. (1993). Methods for non-lethal gill biopsy and measurement of $\mathrm{Na}^{+}, \mathrm{K}^{+}$ATPase activity. Canadian Journal of Fisheries and Aquatic Sciences 50, 656-658.

McCormick, S. D., Regish, A. \& Christensen, A. (2009a). Distinct freshwater and seawater isoforms of $\mathrm{Na}^{+} / \mathrm{K}^{+}$-ATPase in gill chloride cells of Atlantic salmon. Journal of Experimental Biology 212, 3994-4001.

McCormick, S. D., Keyes, A., Nislow, K. H. \& Monette, M. Y. (2009b). Impacts of episodic acidification on in-stream survival and physiological impairment of Atlantic salmon (Salmo salar) smolts. Canadian Journal of Fisheries and Aquatic Sciences 66, 394-403.

Monette, M. Y. \& McCormick, S. D. (2008). Impacts of short-term acid and aluminum exposure on Atlantic salmon (Salmo salar) physiology: a direct comparison of parr and smolts. Aquatic Toxicology 86, 216-226.

Monette, M. Y., Yada, T., Matey, V. \& McCormick, S. D. (2010). Physiological, molecular and cellular mechanisms of impaired seawater tolerance following exposure of Atlantic salmon, Salmo salar, smolts to acid and aluminum. Aquatic Toxicology 99, 17-32.

Neville, C. M. (1985). Physiological response of juvenile rainbow trout, Salmo gairdneri, to acid and aluminum - prediction of field responses from laboratory data. Canadian Journal of Fisheries and Aquatic Sciences 42, 2004-2019.

Nyberg, P., Andersson, P., Degerman, E., Borg, H. \& Olofsson, E. (1995). Labile inorganic manganese - an overlooked reason for fish mortality in acidified streams? Water, Air and Soil Pollution 85, 333-340.

Parrish, D. L., Behnke, R. J., Gephard, S. R., McCormick, S. D. \& Reeves, G. H. (1998). Why aren't there more Atlantic salmon (Salmo salar)? Canadian Journal of Fisheries and Aquatic Sciences 55, 281-287.

Rosseland, B. O., Eldhuset, T. D. \& Staurnes, M. (1990). Environmental effects of aluminum. Environmental Geochemistry and Health 12, 17-27.

Roy, R. L. \& Campbell, P. G. C. (1997). Decreased toxicity of Al to juvenile Atlantic salmon (Salmo salar) in acidic soft water containing natural organic matter: a test of the free-ion model. Environmental Toxicology and Chemistry 16, 1962-1969.

Saunders, R. L., Henderson, E. B., Harmon, P. R., Johnston, C. E. \& Eales, J. G. (1983). Effects of low environmental pH on smolting of Atlantic salmon (Salmo salar). Canadian Journal of Fisheries and Aquatic Sciences 40, 1203-1211.

Schindler, D. W. (1988). Effects of acid rain on freshwater ecosystems. Science 239, 149-157.

Skogheim, O. K., Rosseland, B. O., Hoell, E. \& Kroglund, F. (1986). Base additions to flowing acidic water - effects on smolts of Atlantic salmon (Salmo salar L.). Water, Air, and Soil Pollution 30, 587-592.

Staurnes, M., Blix, P. \& Reite, O. B. (1993). Effects of acid water and aluminum on parrsmolt transformation and seawater tolerance in Atlantic salmon, Salmo salar. Canadian Journal of Fisheries and Aquatic Sciences 9, 1816-1827.

Staurnes, M., Kroglund, F. \& Rosseland, B. O. (1995). Water quality requirement of Atlantic salmon (Salmo salar) in water undergoing acidification or liming in Norway. Water, Air, and Soil Pollution 85, 347-352.

Staurnes, M., Hansen, L., Fugelli, K. \& Haraldstad, O. (1996). Short-term exposure to acid water impairs osmoregulation, seawater tolerance, and subsequent marine survival of smolts of Atlantic salmon (Salmo salar L.). Canadian Journal of Fisheries and Aquatic Sciences 53, 1695-1704.

Stein, M. W. (1963). D-glucose, determination with hexokinase and glucose-6-phosphate dehydrogenase. In Methods in Enzymatic Analysis (Bergmeyer, H. U., ed.), pp. 117. New York, NY: Academic Press. 
Teien, H.-C., Kroglund, F., Salbu, B. \& Rosseland, B. O. (2006). Gill reactivity of aluminiumspecies following liming. Science of the Total Environment 358, 206-220.

Ytrestoyl, T., Finstad, B. \& McKinley, R. S. (2001). Swimming performance and blood chemistry in Atlantic salmon spawners exposed to acid river water with elevated aluminium concentrations. Journal of Fish Biology 58, 1025-1038.

\section{Electronic References}

Fay, C., Bartron, M., Craig, S., Hecht, A., Pruden, J., Saunders, R., Sheehan, T. \& Trial, J. (2006). Status review for anadromous Atlantic salmon (Salmo salar) in the United States. Report to the National Marine Fisheries Service and U.S. Fish and Wildlife Service. Available at http://www.nmfs.noaa.gov/pr/pdfs/statusreviews/atlanticsalmon.pdf/

Johnson, K. \& Kahl, J. S. (2005). A systematic survey of water chemistry for Downeast area rivers. Project Final Report to Maine Atlantic Salmon Commission. Augusta, ME. Available at http://www.umaine.edu/waterresearch/research/nfwf_salmon_water_chemistry. $\mathrm{htm} /$

USEPA (1983). Methods for chemical analysis of water and wastes. EPA/600/4-79-020, 1979, Revised 1983. Washington, DC: U.S. Environmental Protection Agency. Available at www.epa.gov

USEPA (1987). Handbook of methods for acid deposition studies: laboratory analysis for surface water chemistry. EPA/600/4-87-026. Washington, DC: U.S. Environmental Protection Agency. Available at www.epa.gov

USEPA (1993). Methods for the determination of inorganic substances in environmental samples. EPA/600/R-93-100. Washington, DC: U.S. Environmental Protection Agency. Available at www.epa.gov

USEPA (1996). Method 1669. Sampling Ambient Water for Trace Metals at EPA Water Quality Criteria Levels. Washington, DC: U.S. Environmental Protection Agency. Available at www.epa.gov 